\title{
Recent advances in the management of
}

\section{lymphangioleiomyomatosis [version 1; peer review: 4}

\section{approved]}

\author{
Kai-Feng Xu(iD), Xinlun Tian1, Jay H Ryu (iD)2 \\ ${ }^{1}$ Department of Respiratory Medicine, Peking Union Medical College Hospital, Peking Union Medical College and Chinese Academy \\ of Medical Sciences, Beijing, China \\ ${ }^{2}$ Division of Pulmonary and Critical Care Medicine, Mayo Clinic, Rochester, MN, USA
}

\section{V1 First published: 18 Jun 2018, 7(F1000 Faculty Rev):758 \\ https://doi.org/10.12688/f1000research.14564.1}

Latest published: 18 Jun 2018, 7(F1000 Faculty Rev):758

https://doi.org/10.12688/f1000research.14564.1

\begin{abstract}
Lymphangioleiomyomatosis is a rare disorder that predominantly affects women and is characterized by progressive cystic changes in the lung, leading to gradually worsening shortness of breath and lung function impairment. Pleural complications such as pneumothorax and chylothorax commonly occur in these patients.

Lymphangioleiomyomatosis can occur as a form of lung involvement in tuberous sclerosis complex or as a sporadic form (without tuberous sclerosis complex). Etiology in both forms of this disease centers on mutations in the tuberous sclerosis genes. Advances in our understanding of the regulatory role of tuberous sclerosis gene products (hamartin/tuberin) in the mechanistic target of rapamycin (mTOR) signaling pathway have led to the identification of effective therapy (mTOR inhibitors) for a rare disorder, once considered uniformly fatal. Here, we summarize the evolution of current concepts regarding lymphangioleiomyomatosis with an emphasis on recent advances and unresolved issues.
\end{abstract}

\section{Keywords}

Angiomyolipoma, Chylothorax, Lung transplantation, Lymphangioleiomyomatosis, Pneumothorax, Pulmonary rehabilitation, Rapamycin, Sirolimus, Tuberous sclerosis complex

\section{Open Peer Review}

$\begin{array}{rrrr}\text { Approval Status } & \checkmark \\ 1 & 2 & 3 & 4 \\ & & \end{array}$

version 1

18 Jun 2018

Faculty Reviews are review articles written by the prestigious Members of Faculty Opinions. The articles are commissioned and peer reviewed before publication to ensure that the final, published version is comprehensive and accessible. The reviewers who approved the final version are listed with their names and affiliations.

1. Srihari Veeraraghavan, Emory University

School of Medicine, Atlanta, USA

2. Adrian Shifren, Washington University

School of Medicine, St. Louis, USA

3. David Neal Franz, Cincinnati Children's Hospital Medical Center, Cincinnati, USA

4. Nabeel Hamzeh, University of Iowa, Iowa

City, USA

Any comments on the article can be found at the end of the article. 
Corresponding author: Jay H Ryu (ryu.jay@mayo.edu)

Author roles: Xu KF: Conceptualization, Methodology, Project Administration, Validation, Visualization, Writing - Original Draft Preparation, Writing - Review \& Editing; Tian X: Conceptualization, Project Administration, Visualization, Writing - Original Draft Preparation, Writing - Review \& Editing; Ryu JH: Conceptualization, Methodology, Project Administration, Supervision, Validation, Visualization, Writing - Review \& Editing

Competing interests: No competing interests were disclosed.

Grant information: The work of K-FX and XT was supported by the National Nature Science Foundation of China (81570061), the National Key Research and Development Program of China (2016YFC0901502), the Beijing Municipal Science and Technology Project (Z151100003915126), and the Chinese Academy of Medical Sciences (CAMS) Initiative for Innovative Medicine (2017-12M-2-001).

Copyright: @ 2018 Xu KF et al. This is an open access article distributed under the terms of the Creative Commons Attribution License, which permits unrestricted use, distribution, and reproduction in any medium, provided the original work is properly cited.

How to cite this article: $\mathrm{Xu} \mathrm{KF}$, Tian $\mathrm{X}$ and Ryu JH. Recent advances in the management of lymphangioleiomyomatosis [version 1; peer review: 4 approved] F1000Research 2018, 7(F1000 Faculty Rev):758 https://doi.org/10.12688/f1000research.14564.1

First published: 18 Jun 2018, 7(F1000 Faculty Rev):758 https://doi.org/10.12688/f1000research.14564.1 


\section{Introduction}

Lymphangioleiomyomatosis (LAM) is a rare disease that occurs primarily in women and manifests as diffuse cystic changes in the lung ${ }^{1,2}$. The presenting symptoms may include dyspnea or chest pain (often related to spontaneous pneumothorax) or both ${ }^{3,4}$. Some patients may present for evaluation of imaging abnormalities, including cystic lung disease, pleural effusion, or renal tumor (associated renal angiomyolipomas, or AML) in the absence of symptoms.

LAM can be sporadic or occur in patients with a heritable disorder, tuberous sclerosis complex (TSC), and had been considered a lethal disorder with no effective therapy. In 2010, the European Respiratory Society (ERS) published the first clinical guidelines for the diagnosis and management of $\mathrm{LAM}^{3}$. In 2011, sirolimus (rapamycin) therapy was demonstrated to stabilize lung function in patients with $\mathrm{LAM}^{5}$. Currently, LAM is considered a low-grade, metastasizing neoplasm ${ }^{1}$. Advances in our understanding of the disease process in recent years have profoundly changed the management of LAM and the prognosis for affected patients. Table 1 outlines the major events that have influenced clinical practice in recent years ${ }^{3,5-11}$. In this review, we aim to summarize the recent evolution of concepts concerning the state-of-the-art management of LAM.

\section{Sirolimus therapy for lymphangioleiomyomatosis}

Sirolimus, or rapamycin, inhibits the mechanistic target of rapamycin (mTOR) signaling pathway and currently plays a central role in the treatment of LAM. The molecular pathogenesis of LAM is based on TSC2 gene mutations and their effect on the mTOR pathway, which is normally controlled by the protein complex (hamartin/tuberin) encoded by TSC1 and TSC2 genes, respectively ${ }^{12,13}$. When the TSC2 or TSC1 gene is mutated, the resulting protein complex fails in its role as an upstream negative regulator of mTOR and results in its constitutive activation ${ }^{14}$. This mTOR activation, in turn, results in unregulated cell growth.
Based on the discovery of TSC2 mutation in patients with sporadic LAM and the mechanism of action of sirolimus, clinical trials were initiated assessing the efficacy of sirolimus therapy for not only TSC-related tumors but also LAM. In 2008, Bissler et al. published the first clinical trial on the use of sirolimus for renal AMLs in patients with TSC as well as sporadic $\mathrm{LAM}^{6}$. In the 12 -month treatment period, sirolimus significantly reduced the size of AMLs. The pulmonary function measurements for the 11 LAM patients in the study improved as well. Subsequently, a randomized placebo-controlled study of sirolimus for LAM-Multicenter International Lymphangioleiomyomatosis Efficacy of Sirolimus (MILES) studyenrolled 89 patients $^{5}$. The forced expiratory volume at 1 second $\left(\mathrm{FEV}_{1}\right)$ increased or remained stable during 12 months of treatment. The level of serum vascular endothelial growth factor-D (VEGF-D), a biomarker reflecting disease activity, decreased significantly during treatment with sirolimus.

Sirolimus has now been widely administered to patients with LAM. Multiple additional clinical studies on the use of sirolimus for LAM have been published, although the sample sizes of the studies were relatively small because of the rarity of this disease $^{15}$. Overall, sirolimus therapy was demonstrated to stabilize lung function, improve quality of life, reduce the size of chylothorax, decrease the volume of renal AMLs, and decrease serum VEGF-D level ${ }^{16-23}$.

Indications for sirolimus therapy in lymphangioleiomyomatosis Diffuse cystic lung disease can be seen in disorders other than LAM, and the differential diagnosis of diffuse cystic lung disease has been reviewed elsewhere ${ }^{2,24}$. The diagnosis of LAM is classified as "definite", "probable", or "possible" according to the criteria outlined in the 2010 ERS guidelines". The diagnostic criteria for definite LAM were updated recently in the American Thoracic Society/Japanese Respiratory Society (ATS/ JRS) guidelines published in 2017. Accordingly, a definite diagnosis of LAM can be established when a patient has compatible

\section{Table 1. Recent landmark events in the management of lymphangioleiomyomatosis.}

Year Events
2008 Sirolimus is demonstrated to induce regression of TSC- or sporadic LAM-associated renal angiomyolipomas and improve
spirometric measurements in some patients with LAM
.


clinical and radiological findings-diffuse cystic lung disease depicted on high-resolution computed tomography (CT) of the chest-combined with one of the following features: presence of TSC, renal AMLs, chylothorax, lymphangioleiomyomas, elevated serum VEGF-D level, presence of LAM cells demonstrated in effusions or lymph nodes, or histopathological confirmation by biopsy of lung or extrapulmonary lesion. Patients with compatible clinical and radiological features can be diagnosed with "probable" LAM in the absence of additional diagnostic criteria.

Sirolimus therapy is currently recommended for patients with a definite diagnosis of LAM who manifest an abnormal (FEV of less than $70 \%$ of the predicted value) or declining pulmonary function ${ }^{10}$. Other indications for the use of sirolimus in patients with LAM may include symptomatic chylothorax or chylous ascites ${ }^{10}$, renal $\mathrm{AMLs}^{6}$, retroperitoneal or pelvic lymphangioleiomyomas, and other TSC-related lesions ${ }^{15}$.

\section{Optimal dosage of sirolimus therapy in} lymphangioleiomyomatosis

Although optimal dosage of sirolimus for LAM has not been defined, the currently favored dosage for LAM is 1-2 mg per day ("low dose") to achieve a serum trough level of around $5 \mathrm{ng} / \mathrm{mL}$, which is on the lower end of the original target serum trough level in the MILES trial (that is, between 5 and $15 \mathrm{ng} / \mathrm{mL}$ ). In a retrospective analysis of 98 patients with LAM treated with this dosing regimen at Peking Union Medical College Hospital, the majority of patients achieved a trough serum level of $5-10 \mathrm{ng} / \mathrm{mL}$ while about $20 \%$ of patients attained a serum trough level of less than $5 \mathrm{ng} / \mathrm{mL}^{16}$. A study involving 15 patients in Japan suggested that an even lower dosing regimen that achieves a serum trough level of less than $5 \mathrm{ng} / \mathrm{mL}$ may provide treatment effects equivalent to those of higher dosing regimens ${ }^{25}$. Another study reported no association between the rate of change in $\mathrm{FEV}_{1}$ and serum sirolimus level ${ }^{23}$.

We suggest monitoring patients with LAM for progression of the disease while on sirolimus therapy as well as assessing for adverse drug-related effects. Although minimal effective dosage is preferred, higher doses of sirolimus may be needed in patients who continue to manifest disease progression. Table 2 outlines the suggested monitoring schedule for LAM patients on sirolimus therapy ${ }^{26}$.

Safety of sirolimus therapy in lymphangioleiomyomatosis Sirolimus is generally well tolerated in patients with LAM. Common side effects of sirolimus therapy in LAM include acne-like rash, oral ulcer, irregular menses, peripheral edema, diarrhea, hyperlipidemia, and liver enzyme elevations. Sirolimus-associated pneumonitis is rare but can be severe ${ }^{21}$. Pulmonary infections were not increased in patients with LAM treated with sirolimus ${ }^{5}$. The long-term safety profile of sirolimus therapy has not yet been fully defined.

\section{Sirolimus treatment failure}

Not all patients with LAM respond to sirolimus therapy. Currently, there is no consensus regarding the definition of treatment failure in LAM. Additionally, alternative therapeutic intervention for such cases is lacking. A phase I trial has been conducted

Table 2. Suggested schedule of monitoring assessments for lymphangioleiomyomatosis patients on sirolimus therapy.

\begin{tabular}{|c|c|c|c|c|}
\hline Monitoring assessments & $\begin{array}{l}\text { Prior to } \\
\text { therapy }\end{array}$ & $\begin{array}{l}\text { Initial } 3 \\
\text { months }\end{array}$ & $\begin{array}{l}\text { Every 6-12 } \\
\text { months }\end{array}$ & $\begin{array}{l}\text { In case of clinical } \\
\text { worsening }\end{array}$ \\
\hline Clinical & $\checkmark$ & $\checkmark$ & $\checkmark$ & $\checkmark$ \\
\hline Pulse oximetry & $\checkmark$ & $\checkmark$ & $\checkmark$ & $\checkmark$ \\
\hline Six-minute walking distance (6MWD) & $\checkmark$ & & $\checkmark$ & $\checkmark$ \\
\hline St George Respiratory Questionnaire & $\checkmark$ & & $\checkmark$ & $\checkmark$ \\
\hline Pulmonary function test & $\checkmark$ & & $\checkmark$ & $\checkmark$ \\
\hline $\begin{array}{l}\text { Serum vascular endothelial growth factor-D (VEGF-D) } \\
\text { level }\end{array}$ & $\checkmark$ & & $\boldsymbol{J}^{\mathrm{a}}$ & $\Omega^{a}$ \\
\hline High-resolution computed tomography (HRCT) of chest & $\checkmark$ & & $\boldsymbol{J}^{\mathrm{b}}$ & $\boldsymbol{S}^{\mathrm{a}}$ \\
\hline $\begin{array}{l}\text { Computed tomography/magnetic resonance imaging } \\
\text { of abdomen and pelvis }\end{array}$ & $\checkmark$ & & $\Omega^{c}$ & $\Omega^{c}$ \\
\hline Sirolimus concentration & & $\Omega^{d}$ & $\checkmark$ & $\checkmark$ \\
\hline Sirolimus safety & & $\checkmark$ & $\checkmark$ & $\checkmark$ \\
\hline \multicolumn{5}{|l|}{ aptional depending on the clinical requirements. } \\
\hline \multicolumn{5}{|c|}{ b HRCT of the chest can be assessed every 12 months or as clinically indicated. } \\
\hline \multicolumn{5}{|c|}{ If abnormal at baseline or prior to therapy and as clinically indicated. } \\
\hline \multicolumn{5}{|c|}{$\begin{array}{l}\text { The sirolimus dosage should be adjusted during the initial } 3 \text { months of treatment, if needed, and when necessary (for example, change in } \\
\text { patient's other medications that may influence serum sirolimus level). }\end{array}$} \\
\hline \multicolumn{5}{|c|}{ e Including symptoms (rash, oral ulcer, menses, and so on) and laboratory investigations (lipid panel and so on). } \\
\hline \multicolumn{5}{|c|}{ Modified from Xu and Lo ${ }^{26}$. } \\
\hline
\end{tabular}


using the combination of sirolimus and hydroxychloroquine (an autophagy inhibitor) and demonstrated the safety of this combination therapy ${ }^{27}$. A phase II study of aromatase inhibitor, letrozole, showed this mode of therapy to be safe and well tolerated but, owing in part to under-enrollment of study participants, failed to show efficacy ${ }^{28}$. Future studies are needed to clarify the definition of sirolimus treatment failure, underlying mechanisms, and optimal management strategies for affected patients.

\section{Pulmonary rehabilitation}

Pulmonary rehabilitation is a standard practice for patients with chronic lung diseases ${ }^{29}$. It can reduce dyspnea, increase exercise capacity, and improve quality of life. A controlled clinical trial consisting of 40 patients with LAM examined the effects of pulmonary rehabilitation ${ }^{30}$. The program included twice-weekly 1 -hour sessions of aerobic exercise on a treadmill and muscle strength training along with education for a period of 3 months. The pulmonary rehabilitation group exhibited improved exercise endurance time, quality of life, 6-minute walking distance, and peak oxygen consumption. No cases of pneumothorax or other serious events occurred during exercise. These results suggest that a pulmonary rehabilitation program should be employed in dyspneic patients with LAM. A study of yoga therapy in patients with LAM is ongoing in China (ChiCTR-OON-17012748, http://www.chictr.org.cn/showproj. aspx?proj=21738).

\section{Lung transplantation}

Lung transplantation is a treatment option for patients with advanced $\mathrm{LAM}^{3}$. Similar experiences have been reported from multiple countries on the use of lung transplantation in $\mathrm{LAM}^{31-36}$. The ERS guidelines recommended that patients with LAM be considered for lung transplantation when they reach a New York Heart Association (NYHA) functional class of III or IV with severely impaired lung function and exercise capacity ${ }^{3}$. Prior pleurodesis and thoracic surgical procedures are associated with higher rates of bleeding and re-exploration but are not contraindications to lung transplantation ${ }^{11,37}$. The actuarial survival of lung transplant recipients with LAM is $65 \%$ at 5 years ${ }^{3}$.

Sirolimus is a potent immunosuppressant and is commonly used in solid organ transplant recipients to prevent organ rejection. There have been reports of impaired wound healing and wound dehiscence associated with sirolimus therapy ${ }^{38-40}$. Given these concerns, questions have arisen regarding whether sirolimus therapy should be discontinued when patients with LAM are on a waiting list for lung transplantation and the safety of including sirolimus in the post-transplant immunosuppressive regimen.

When patients are on a waiting list for lung transplantation, most lung transplant programs advise patients to discontinue sirolimus therapy ${ }^{39}$. However, the cessation of sirolimus therapy introduces the risk of disease progression and worsening in lung function in patients with LAM. It has been suggested that keeping patients on sirolimus therapy, particularly at a low-dose regimen, is likely safe for patients awaiting lung transplantation ${ }^{39}$. Nonetheless, a consensus exists that sirolimus not be used in the immediate post-lung transplant period to minimize the risk of bronchial anastomotic dehiscence. Longterm benefits of reinitiating sirolimus therapy after bronchial anastomotic healing has occurred remain to be determined. These potential benefits may include prevention of LAM recurrence in the transplanted lung, reducing the risk of pleural complications (for example, chylothorax), and control of extrapulmonary manifestations (for example, renal AMLs).

\section{Other management issues in lymphangioleiomyomatosis} Pneumothorax

Pneumothorax occurs commonly in patients with LAM. A National Heart, Lung, and Blood Institute (NHLBI) registry study of 230 patients with LAM reported pneumothorax to have occurred in $55.5 \%$ of subjects at enrollment into the study ${ }^{4}$. Recurrence of pneumothorax is also common, occurring on average 4.4 times among those with a history of pneumothorax ${ }^{4}$. Because the recurrence rate is high, current guidelines recommend pleurodesis at the time of the first episode of pneumothorax ${ }^{3,11}$. However, pleurodesis in patients with LAM has limited efficacy and the recurrence rate of pneumothorax is reported to range between $18 \%$ and $32 \%{ }^{11,41}$. Therefore, more reliable methods to reduce the risk of recurrent pneumothorax in these patients have been sought. Kurihara et al. reported a new surgical technique using oxidized regenerated cellulose mesh to wrap the visceral pleura in a procedure called "total pleural covering" (TPC) $)^{42}$. They retrospectively analyzed 43 LAM patients who underwent the TPC procedure (54 hemithoraces), 11 of whom required bilateral lung surgeries. A Kaplan-Meier estimate of recurrence-free hemithorax was $80.8 \%$ at 2.5 years.

\section{Chylothorax}

Chylothorax occurs in about $7-10 \%$ of patients with LAM $^{4,43,44}$. The clinical effects and prognosis associated with chylothorax vary considerably ${ }^{43,45}$. Several different types of lymphatic abnormalities associated with chylothorax have been identified by CT and lymphangiography ${ }^{46}$. Iliac or retroperitoneal lymphatic vessel dilation and obstruction of the thoracic duct are most commonly observed. Although the majority of physicians believe that LAM patients with chylothorax should be provided a low-fat or fat-free diet, the use of such dietary maneuvers requires monitoring of the nutritional status to avoid malnutrition ${ }^{3}$. Observation or drainage by thoracentesis may be sufficient for patients with a small chylothorax ${ }^{3}$. Prior to sirolimus therapy, various surgical techniques, including pleurodesis, serial thoracenteses, and thoracic duct ligation, were employed in patients with varying degrees of efficacy ${ }^{43,47,48}$.

Currently, the most effective management for chylothorax associated with LAM is considered sirolimus therapy. Initial reports on the beneficial effects of sirolimus therapy in managing chylothorax associated with LAM were published in $2008^{49,50}$. Subsequent studies have confirmed the effectiveness of sirolimus therapy on controlling chylothorax ${ }^{16,25,51,52}$.

Renal angiomyolipoma

Renal AMLs are found in about $30 \%$ of patients with sporadic LAM and $90 \%$ of those with TSC-related LAM ${ }^{4}$. Previously, the management of renal AMLs included embolization 
therapy or nephron-sparing surgery for tumors larger than $4 \mathrm{~cm}^{3}$. Clinical practice has changed since the advent of mTOR inhibitor therapy (that is, sirolimus or everolimus) for LAM and TSC-related manifestations. It is now well established that sirolimus effectively reduces the size of renal AMLs. In a report from Bissler et al., sirolimus reduced the volume of renal AMLs by about half after 1 year of treatment ${ }^{6}$. In a randomized placebo-controlled trial of everolimus for renal AMLs associated with sporadic LAM or TSC (EXIST-2), $42 \%$ of patients achieved a response defined as $50 \%$ reduction of tumor volume $^{53}$. A total of $58 \%$ of 112 patients achieved a response during a 4-year extension period of the study, while none of the treated patients experienced bleeding of the tumor or needed nephrectomy ${ }^{54}$. Other studies have confirmed the effectiveness of sirolimus therapy for renal AMLs ${ }^{16,17,22}$.

\section{Pulmonary hypertension}

Pulmonary hypertension (PH) can be seen in patients with LAM with an estimated prevalence of $7 \%$ to $8 \%{ }^{55-57}$. PH is usually mild to moderate in severity but can be associated with significant impact on functional capacity ${ }^{55-57}$. The mechanisms underlying $\mathrm{PH}$ may include hypoxemia (including exertionrelated oxygen desaturation) and pulmonary vascular remodeling. Hemodynamic parameters tend to correlate with pulmonary function, especially $\mathrm{FEV}_{1}$, diffusion capacity of the lung for carbon monoxide (DLCO), and alveolar-arterial oxygen $\left(\mathrm{PA}-\mathrm{aO}_{2}\right)$ gradient. A recent report suggests that $\mathrm{PH}$ may improve with sirolimus therapy ${ }^{58}$.

\section{Air travel}

Ambient barometric pressure change that occurs during air travel has raised concerns regarding the risk of pneumothorax during flight for patients with cystic lung disease such as LAM. A survey study of 327 patients with LAM reported a rate of $2.2 \%$ for pneumothorax in flight ${ }^{59}$. Other reported symptoms during air travel included chest pain, dyspnea, hypoxemia, nausea, dizziness, fatigue, headache, hemoptysis, and anxiety. Another study, of 281 patients with LAM, found a pneumothorax rate of $1.1 \%$ per flight ${ }^{60}$.

Although the incidence of pneumothorax associated with air travel is low, advice regarding air travel should be formulated carefully on an individual basis ${ }^{61}$. Patients with existing pneumothorax should avoid air travel. Patients who have recovered from pneumothorax or thoracic surgery should delay air travel for a period of a few weeks, until full resolution and healing have been achieved. Patients with symptoms of chest pain, severe dyspnea, or low oxygen saturation should be medically evaluated in advance of planned air travel.

\section{Pregnancy}

LAM-associated complications, including pneumothorax and chylothorax, may occur during pregnancy, and concerns have been raised regarding possible association of pregnancy with progression of $\mathrm{LAM}^{62,63}$. Women with LAM have also been reported to experience worse pregnancy outcomes, including a greater number of premature births and miscarriages ${ }^{62,63}$.
Women with LAM should be informed of these increased risks associated with pregnancy ${ }^{3}$. Patients with mild or moderate LAM will likely tolerate pregnancy better compared with those with more severe disease. The decision to proceed to pregnancy is a personal one that is made on an individual basis after assessing the severity of LAM, potential risks, and other options to pregnancy. During pregnancy, the patient should be monitored carefully by a multidisciplinary team that can optimally manage a high-risk pregnancy.

Sirolimus is included in the $\mathrm{C}$ risk category (risk to fetus has not been ruled out, and adverse effect to the fetus has been shown in animal studies but no adequate studies of humans) for US Food and Drug Administration pregnancy labeling. There are reports of successful pregnancy without teratogenicity in solid organ transplant recipients receiving sirolimus. Currently, initiation of contraception is recommended before starting sirolimus therapy and continued for 12 weeks after discontinuation.

\section{Avoidance of exogenous estrogen}

Several lines of observation suggest that estrogen promotes the growth and spread of LAM cells. For example, LAM occurs mostly in women and seems to manifest slowing of disease progression after menopause. There are in vitro data demonstrating that neoplastic potential and survival of LAM cells are enhanced by estrogen ${ }^{64}$. Thus, it is generally advised that exogenous estrogen exposure (for example, estrogen replacement therapy) be avoided for patients with LAM.

\section{Summary}

Not long ago, LAM was considered a uniformly fatal lung disease for those who became afflicted with this rare and poorly understood condition. Remarkable progress has occurred, particularly over the past decade, leading to effective medical therapy that prevents progression of disease for most patients. There are unanswered questions regarding the long-term efficacy and safety of mTOR inhibitor therapy for the treatment of LAM. In addition, there is a need to identify other medical treatment options for those patients who experience disease progression despite mTOR inhibition.

\section{Competing interests}

The authors declare that they have no competing interests.

\section{Grant information}

The work of K-FX and XT was supported by the National Nature Science Foundation of China (81570061), the National Key Research and Development Program of China (2016YFC0901502), the Beijing Municipal Science and Technology Project (Z151100003915126), and the Chinese Academy of Medical Sciences (CAMS) Initiative for Innovative Medicine (2017-12M-2-001).

The funders had no role in study design, data collection and analysis, decision to publish, or preparation of the manuscript. 
1. F McCormack FX, Travis WD, Colby TV, et al:: Lymphangioleiomyomatosis: calling it what it is: a low-grade, destructive, metastasizing neoplasm. Am J Respir Crit Care Med. 2012; 186(12): 1210-2.

PubMed Abstract | Publisher Full Text | Free Full Text | F1000 Recommendation

2. Ryu JH, Tian X, Baqir M, et al.: Diffuse cystic lung diseases. Front Med. 2013; 7(3): 316-27.

PubMed Abstract | Publisher Full Tex

3. F Johnson SR, Cordier JF, Lazor R, et al.: European Respiratory Society guidelines for the diagnosis and management of lymphangioleiomyomatosis. Eur Respir J. 2010; 35(1): 14-26.

PubMed Abstract | Publisher Full Text | F1000 Recommendation

4. Ryu JH, Moss J, Beck GJ, et al.: The NHLBI lymphangioleiomyomatosis registry: characteristics of 230 patients at enrollment. Am J Respir Crit Care Med. 2006; 173(1): 105-11.

PubMed Abstract | Publisher Full Text | Free Full Text

5. $\quad F$ McCormack FX, Inoue $Y$, Moss J, et al: Efficacy and safety of sirolimus in lymphangioleiomyomatosis. N Engl J Med. 2011; 364(17): 1595-606. PubMed Abstract | Publisher Full Text | Free Full Text | F1000 Recommendation

6. F Bissler JJ, McCormack FX, Young LR, et al:: Sirolimus for angiomyolipoma in tuberous sclerosis complex or lymphangioleiomyomatosis. $N$ Engl $J$ Med. 2008: 358(2): 140-51.

PubMed Abstract | Publisher Full Text | Free Full Text | F1000 Recommendation

7. Northrup H, Krueger DA, International Tuberous Sclerosis Complex Consensus Group: Tuberous Sclerosis Complex Diagnostic Criteria Update: Recommendations of the $\mathbf{2 0 1 2}$ International Tuberous Sclerosis Complex Consensus Conference. Pediatr Neurol. 2013; 49(4): 243-54. PubMed Abstract | Publisher Full Text | Free Full Text

8. Krueger DA, Northrup H, International Tuberous Sclerosis Complex Consensus Group: Tuberous sclerosis complex surveillance and management: recommendations of the 2012 International Tuberous Sclerosis Complex Consensus Conference. Pediatr Neurol. 2013; 49(4): 255-65. PubMed Abstract | Publisher Full Text | Free Full Text

9. F Travis WD, Brambilla E, Nicholson AG, et al:: The $\mathbf{2 0 1 5}$ World Health Organization Classification of Lung Tumors: Impact of Genetic, Clinical and Radiologic Advances Since the 2004 Classification. J Thorac Oncol. 2015; 10(9): 1243-60.

PubMed Abstract | Publisher Full Text | F1000 Recommendation

10. McCormack FX, Gupta N, Finlay GR, et al.: Official American Thoracic Society/Japanese Respiratory Society Clinical Practice Guidelines: Lymphangioleiomyomatosis Diagnosis and Management. Am J Respir Crit Car Med. 2016; 194(6): 748-61.

PubMed Abstract | Publisher Full Text | Free Full Text

11. Gupta N, Finlay GA, Kotloff RM, et al.: Lymphangioleiomyomatosis Diagnosis and Management: High-Resolution Chest Computed Tomography, Transbronchial Lung Biopsy, and Pleural Disease Management. An Official American Thoracic Society/Japanese Respiratory Society Clinical Practice Guideline. Am J Respir Crit Care Med. 2017; 196(10): 1337-48. PubMed Abstract | Publisher Full Text | Free Full Text

12. Carsillo T, Astrinidis A, Henske EP: Mutations in the tuberous sclerosis comple gene TSC2 are a cause of sporadic pulmonary lymphangioleiomyomatosis. Proc Natl Acad Sci U S A. 2000; 97(11): 6085-90. PubMed Abstract | Publisher Full Text | Free Full Text

13. Krymskaya VP, McCormack FX: Lymphangioleiomyomatosis: A Monogenic Model of Malignancy. Annu Rev Med. 2017; 68: 69-83.

PubMed Abstract | Publisher Full Text | Free Full Text

14. El-Hashemite N, Zhang H, Henske EP, et al:: Mutation in TSC2 and activation of mammalian target of rapamycin signalling pathway in renal angiomyolipoma. Lancet. 2003; 361(9366): 1348-9.

PubMed Abstract | Publisher Full Text

15. Xu K, Tian X, Yang Y, et al.: Rapamycin for lymphangioleiomyomatosis: optimal timing and optimal dosage. Thorax. 2018; 73(4): 308-10. PubMed Abstract | Publisher Full Text

16. Zhan $\mathrm{Y}$, Shen $\mathrm{L}, \mathrm{Xu} \mathrm{W}$, et al:: Functional improvements in patients with lymphangioleiomyomatosis after sirolimus: an observational study. Orphanet $J$ Rare Dis. 2018; 13(1): 34 PubMed Abstract | Publisher Full Text | Free Full Text

17. F Davies DM, de Vries PJ, Johnson SR, et al:: Sirolimus therapy for angiomyolipoma in tuberous sclerosis and sporadic lymphangioleiomyomatosis: a phase 2 trial. Clin Cancer Res. 2011; 17(12): 4071-81.

PubMed Abstract | Publisher Full Text | F1000 Recommendation

18. F Neurohr C, Hoffmann AL, Huppmann P, et al:: Is sirolimus a therapeutic option for patients with progressive pulmonary lymphangioleiomyomatosis? Respir Res. 2011; 12(1): 66.

PubMed Abstract | Publisher Full Text | Free Full Text | F1000 Recommendation

19. F Taveira-DaSilva AM, Hathaway O, Stylianou M, et al.: Changes in lung function and chylous effusions in patients with lymphangioleiomyomatosis treated with sirolimus. Ann Intern Med. 2011; 154(12): 797-805, W-292-3. PubMed Abstract | Publisher Full Text | Free Full Text | F1000 Recommendation
20. F Yao J, Taveira-DaSilva AM, Jones AM, et al.: Sustained effects of sirolimus n lung function and cystic lung lesions in lymphangioleiomyomatosis. $A m$ Respir Crit Care Med. 2014; 190(11): 1273-82.

PubMed Abstract | Publisher Full Text | Free Full Text | F1000 Recommendation

21. F Takada T, Mikami A, Kitamura N, et al.: Efficacy and Safety of Long-Term Sirolimus Therapy for Asian Patients with Lymphangioleiomyomatosis. Ann Am Thorac Soc. 2016: 13(11): 1912-22.

PubMed Abstract | Publisher Full Text | F1000 Recommendation

22. Taveira-DaSilva AM, Jones AM, Julien-Williams $\mathrm{P}$, et al.: Long-Term Effect of Sirolimus on Serum Vascular Endothelial Growth Factor D Levels in Patients With Lymphangioleiomyomatosis. Chest. 2018; 153(1): 124-32. PubMed Abstract | Publisher Full Text | Free Full Text

23. F Bee J, Fuller S, Miller S, et al.: Lung function response and side effects to rapamycin for lymphangioleiomyomatosis: a prospective national cohort study. Thorax. 2018; 73(4): 369-75.

PubMled Abstract | Publisher Full Text | F1000 Recommendation

24. Xu KF, Feng R, Cui H, et al.: Diffuse Cystic Lung Diseases: Diagnostic Considerations. Semin Respir Crit Care Med. 2016: 37(3): 457-67. PubMed Abstract | Publisher Full Text

25. Ando $\mathrm{K}$, Kurihara $\mathrm{M}$, Kataoka $\mathrm{H}$, et al.: Efficacy and safety of low-dose sirolimus for treatment of lymphangioleiomyomatosis. Respir Investig. 2013; 51(3): 175-83. PubMed Abstract | Publisher Full Text

26. Xu K, Lo BH: Lymphangioleiomyomatosis: differential diagnosis and optimal management. Ther Clin Risk Manag. 2014; 10: 691-700. PubMed Abstract | Publisher Full Text |Free Full Text

27. F El-Chemaly S, Taveira-Dasilva A, Goldberg HJ, et al:: Sirolimus and Autophagy Inhibition in Lymphangioleiomyomatosis: Results of a Phase I Clinical Trial. Chest. 2017; 151(6): 1302-10.

PubMed Abstract | Publisher Full Text | F1000 Recommendation

28. F Lu C, Lee H, Pappas GP, et al: A Phase II Clinical Trial of an Aromatase Inhibitor for Postmenopausal Women with Lymphangioleiomyomatosis. Ann Am Thorac Soc. 2017: 14(6): 919-28.

PubMed Abstract | Publisher Full Text | F1000 Recommendation

29. Spruit MA, Singh SJ, Garvey C, et al.: An official American Thoracic Society/ European Respiratory Society statement: key concepts and advances in pulmonary rehabilitation. Am J Respir Crit Care Med. 2013; 188(8): e13-64. PubMed Abstract | Publisher Full Text

30. F Araujo MS, Baldi BG, Freitas CS, et al.: Pulmonary rehabilitation in lymphangioleiomyomatosis: a controlled clinical trial. Eur Respir J. 2016; 47(5): $1452-60$

PubMed Abstract | Publisher Full Text | F1000 Recommendation

31. F Baldi BG, Samano MN, Campos SV, et al.: Experience of Lung Transplantation in Patients with Lymphangioleiomyomatosis at a Brazilian Reference Centre. Lung. 2017; 195(6): 699-705. PubMed Abstract | Publisher Full Text | F1000 Recommendation

32. $\mathrm{F}$ Ando $\mathrm{K}$, Okada $\mathrm{Y}$, Akiba $\mathrm{M}$, et al.: Lung Transplantation for Lymphangioleiomyomatosis in Japan. PLoS One. 2016; 11(1): e0146749. PubMled Abstract | Publisher Full Text | Free Full Text | F1000 Recommendation

33. Ussavarungsi $\mathrm{K}, \mathrm{Hu} \mathrm{X}, \mathrm{Scott} \mathrm{JP}$, et al:: Mayo clinic experience of lung transplantation in pulmonary lymphangioleiomyomatosis. Respir Med. 2015; 109(10): 1354-9.

PubMed Abstract | Publisher Full Text

34. $\mathrm{F}$ Nakagiri $\mathrm{T}$, Shintani $\mathrm{Y}$, Minami M, et al:: Lung Transplantation for ymphangioleiomyomatosis in a Single Japanese Institute, With a Focus on Late-onset Complications. Transplant Proc. 2015; 47(6): 1977-82. PubMed Abstract | Publisher Full Text | F1000 Recommendation

35. Benden C, Rea F, Behr J, et al:: Lung transplantation for lymphangioleiomyomatosis: the European experience. J Heart Lung Transplant. 2009; 28(1): 1-7. PubMed Abstract | Publisher Full Text

36. Kpodonu J, Massad MG, Chaer RA, et al.: The US experience with lung transplantation for pulmonary lymphangioleiomyomatosis. J Heart Lung Transplant. 2005; 24(9): 1247-53.

PubMed Abstract | Publisher Full Tex

37. F Weill D, Benden C, Corris PA, et al:: A consensus document for the selection of lung transplant candidates: 2014--an update from the Pulmonary Transplantation Council of the International Society for Heart and Lung Transplantation. J Heart Lung Transplant. 2015; 34(1): 1-15. PubMled Abstract | Publisher Full Text | F1000 Recommendation

38. F Kaplan B, Qazi Y, Wellen JR: Strategies for the management of adverse events associated with mTOR inhibitors. Transplant Rev (Orlando). 2014; 28(3): 126-33.

PubMed Abstract | Publisher Full Text | F1000 Recommendation

39. F El-Chemaly S, Goldberg HJ, Glanville AR: Should mammalian target of rapamycin inhibitors be stopped in women with lymphangioleiomyomatosis awaiting lung transplantation? Expert Rev Respir Med. 2014; 8(6): 657-60. PubMed Abstract | Publisher Full Text | F1000 Recommendation 
40. Nashan B, Citterio F: Wound healing complications and the use of mammalian target of rapamycin inhibitors in kidney transplantation: a critical review of the literature. Transplantation. 2012; 94(6): 547-61.

PubMed Abstract | Publisher Full Text

41. Almoosa KF, Ryu JH, Mendez J, et al.: Management of pneumothorax in lymphangioleiomyomatosis: effects on recurrence and lung transplantation complications. Chest. 2006; 129(5): 1274-81. PubMed Abstract | Publisher Full Text

42. F Kurihara M, Mizobuchi T, Kataoka H, et al.: A Total Pleural Covering for Lymphangioleiomyomatosis Prevents Pneumothorax Recurrence. PLoS One. 2016; 11(9): e0163637.

PubMed Abstract | Publisher Full Text | Free Full Text | F1000 Recommendation

43. Ryu JH, Doerr $\mathrm{CH}$, Fisher SD, et al.: Chylothorax in lymphangioleiomyomatosis. Chest. 2003; 123(2): 623-7.

PubMed Abstract | Publisher Full Text

44. Ye L, Jin M, Bai C: Clinical analysis of patients with pulmonary lymphangioleiomyomatosis (PLAM) in mainland China. Respir Med. 2010; 104(10): 1521-6

PubMed Abstract | Publisher Full Text

45. Taveira-DaSilva AM, Pacheco-Rodriguez G, Moss J: The natural history of lymphangioleiomyomatosis: markers of severity, rate of progression and prognosis. Lymphat Res Biol. 2010; 8(1): 9-19.

PubMed Abstract | Publisher Full Text | Free Full Text

46. $\mathrm{F}$ Zhang $\mathrm{C}$, Chen $\mathrm{X}$, Wen $\mathrm{T}$, et al:: Computed tomography lymphangiography findings in 27 cases of lymphangioleiomyomatosis. Acta Radiol. 2017; 58(11): 1342-8.

PubMed Abstract | Publisher Full Text | F1000 Recommendation

47. Kaptanoglu M, Hatipoglu A, Kutluay L, et al.: Bilateral chylothorax caused by pleuropulmonary lymphangiomyomatosis: a challenging problem in thoracic surgery. Scand Cardiovasc J. 2001; 35(2): 151-4. PubMed Abstract | Publisher Full Text

48. F Liu M, Wu B, Cui Y, et al.: Surgical treatment of chylothorax caused by lymphangioleiomyomatosis. J Thorac Dis. 2014; 6(2): E11-4. PubMed Abstract | Publisher Full Text | Free Full Text | F1000 Recommendation

49. Sugimoto R, Nakao A, Yamane M, et al:: Sirolimus amelioration of clinical symptoms of recurrent lymphangioleiomyomatosis after living-donor lobar lung transplantation. J Heart Lung Transplant. 2008; 27(8): 921-4. PubMed Abstract | Publisher Full Text

50. Ohara T, Oto T, Miyoshi K, et al.: Sirolimus ameliorated post lung transplant chylothorax in lymphangioleiomyomatosis. Ann Thorac Surg. 2008; 86(6): e7-8. PubMed Abstract | Publisher Full Text

51. Barrera $\mathrm{P}$, Simons SO, Luijk B, et al.: Efficacy of sirolimus therapy for chylous effusions in lymphangioleiomyomatosis. Ann Am Thorac Soc. 2013; 10(4): 408-9. PubMed Abstract | Publisher Full Text

52. F Lama A, Ferreiro L, Golpe A, et al:: Characteristics of Patients with Lymphangioleiomyomatosis and Pleural Effusion: A Systematic Review.
Respiration. 2016; 91(3): 256-64

PubMed Abstract | Publisher Full Text | F1000 Recommendation

53. F Bissler JJ, Kingswood JC, Radzikowska E, et al.: Everolimus for angiomyolipoma associated with tuberous sclerosis complex or sporadic lymphangioleiomyomatosis (EXIST-2): a multicentre, randomised, doubleblind, placebo-controlled trial. Lancet. 2013; 381(9869): 817-24. PubMed Abstract | Publisher Full Text | F1000 Recommendation

54. F Bissler JJ, Kingswood JC, Radzikowska E, et al.: Everolimus long-term use in patients with tuberous sclerosis complex: Four-year update of the EXIST-2 study. PLoS One. 2017; 12(8): e0180939.

PubMed Abstract | Publisher Full Text | Free Full Text | F1000 Recommendation

55. Taveira-DaSilva AM, Hathaway OM, Sachdev V, et al.: Pulmonary artery pressure in lymphangioleiomyomatosis: an echocardiographic study. Chest. 2007; 132(5): 1573-8.

PubMed Abstract | Publisher Full Text | Free Full Text

56. Cottin V, Harari S, Humbert M, et al.: Pulmonary hypertension in lymphangioleiomyomatosis: characteristics in 20 patients. Eur Respir J. 2012 40(3): 630-40.

PubMed Abstract | Publisher Full Text

57. F Freitas CSG, Baldi BG, Jardim C, et al.: Pulmonary hypertension in lymphangioleiomyomatosis: prevalence, severity and the role of carbon monoxide diffusion capacity as a screening method. Orphanet J Rare Dis. 2017; 12(1): 74

PubMed Abstract | Publisher Full Text | Free Full Text | F1000 Recommendation

58. Wu X, Xu W, Wang J, et al:: Clinical characteristics in lymphangioleiomyomatosisrelated pulmonary hypertension: an observation on 50 patients. Front Med. 2018.

PubMed Abstract | Publisher Full Text

59. Pollock-BarZiv S, Cohen MM, Downey GP, et al.: Air travel in women with lymphangioleiomyomatosis. Thorax. 2007; 62(2): 176-80. PubMed Abstract | Publisher Full Text | Free Full Text

60. Taveira-DaSilva AM, Burstein D, Hathaway OM, et al:: Pneumothorax after air travel in lymphangioleiomyomatosis, idiopathic pulmonary fibrosis, and sarcoidosis. Chest. 2009; 136(3): 665-70.

PubMed Abstract | Publisher Full Text | Free Full Text

61. Hu X, Cowl CT, Baqir M, et al.: Air travel and pneumothorax. Chest. 2014; 145(4): 688-94.

PubMed Abstract | Publisher Full Text

62. Johnson SR, Tattersfield AE, et al:: Clinical experience of lymphangioleiomyomatosis in the UK. Thorax. 2000; 55(12): 1052-7. PubMed Abstract | Publisher Full Text | Free Full Text

63. Cohen MM, Freyer AM, Johnson SR: Pregnancy experiences among women with lymphangioleiomyomatosis. Respir Med. 2009; 103(5): 766-72. PubMed Abstract | Publisher Full Text

64. Henske EP, McCormack FX: Lymphangioleiomyomatosis - a wolf in sheep's clothing. J Clin Invest. 2012; 122(11): 3807-16. PubMed Abstract | Publisher Full Text | Free Full Text 


\section{Open Peer Review}

\section{Current Peer Review Status:}

\section{Editorial Note on the Review Process}

Faculty Reviews are review articles written by the prestigious Members of Faculty Opinions. The articles are commissioned and peer reviewed before publication to ensure that the final, published version is comprehensive and accessible. The reviewers who approved the final version are listed with their names and affiliations.

\section{The reviewers who approved this article are:}

\section{Version 1}

\section{Nabeel Hamzeh}

Department of Internal Medicine, University of Iowa, Iowa City, USA

Competing Interests: No competing interests were disclosed.

\section{David Neal Franz}

Cincinnati Children's Hospital Medical Center, Cincinnati, OH, USA

Competing Interests: No competing interests were disclosed.

\section{Adrian Shifren}

Department of Internal Medicine, Washington University School of Medicine, St. Louis, Missouri, USA Competing Interests: No competing interests were disclosed.

\section{Srihari Veeraraghavan}

Division of Pulmonary, Allergy and Critical Care, Emory University School of Medicine, Atlanta, Georgia, USA

Competing Interests: No competing interests were disclosed. 
The benefits of publishing with F1000Research:

- Your article is published within days, with no editorial bias

- You can publish traditional articles, null/negative results, case reports, data notes and more

- The peer review process is transparent and collaborative

- Your article is indexed in PubMed after passing peer review

- Dedicated customer support at every stage

For pre-submission enquiries, contact research@f1000.com 